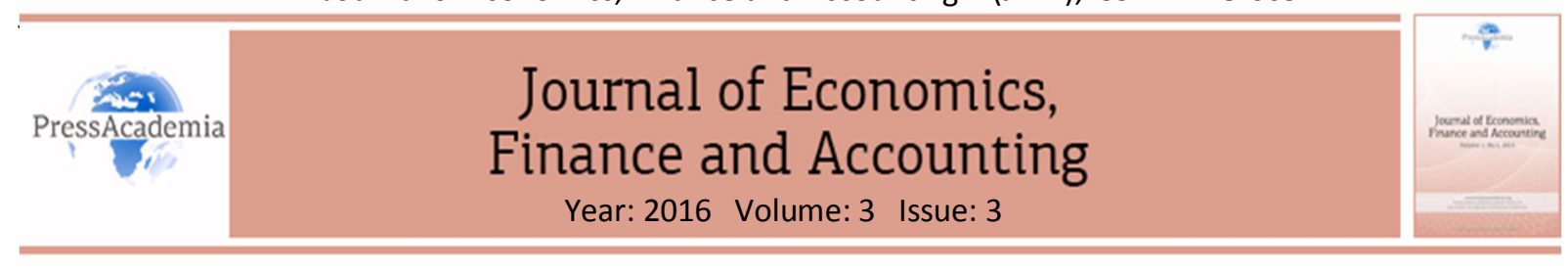

\title{
THE TONE OF ANNUAL REPORTS AS A STRATEGIC PERFORMANCE MANAGEMENT TOOL: APPLICATION ON TURKEY'S BORSA ISTANBUL CORPORATE GOVERNANCE INDEX FIRMS
}

\author{
DOI: 10.17261/Pressacademia.2016321989
}

\section{Eyup Kahveci}

The Central Bank of the Republic of Turkey. eyup.kahveci@tcmb.gov.tr

\begin{abstract}
The annual reports have been identified as one of the key corporate governance practice. If these reports are genuinely being prepared in an attempt to improve the clarity of communication with stakeholders, and give related and necessary information accurately to them, then they become one of the strategic tools affecting performance positively. Therefore, in this study, we aimed a semantic examination of the English versions of annual reports from companies quoted on Borsa Istanbul included in the Corporate Governance Index to see whether the annual reports' tone has an impact on company performance. With this aim, the contents of 2014 annual reports are analyzed by the text-analysis software package Diction 7 and scores for accomplishment, cooperation, activity and optimism are obtained. Efficiency scores are calculated by Data Envelopment Analysis to evaluate to what extent annual reports' tone and corporate governance ratings impact on company performance. The results show that the annual reports' tone and corporate governance ratings have a significant positive impact on efficiency scores, so on performances of companies.
\end{abstract}

Keywords: Corporate governance, DEA efficiency, annual reports, content analysis, firm performance.

JEL Classification: G30, L25, M10

\section{INTRODUCTION}

Informing all interested parties about a company's financial situation, performance, ownership structure, strategies and other conditions, and all related information in a timely and accurate manner is strategically important to surviving and prospering in the long term. In this context, the annual reports of companies are crucial, since they summarize and explain the financial and economic performance of the company, its strategies and accomplishments and future cooperation and expectations to all shareholders. Companies are becoming aware that the annual report is a potential tool for clients, investors, all shareholders and stakeholders.

Studies have indicated that annual reports to shareholders and the president's letter they contain are important vehicles for communicating information to shareholders and other interested stakeholders. Most corporate officers see annual reports as their primary channel to shareholders (Abrahamson \& Park, 1994).

The annual report has been identified as one of the key corporate governance practices, and specifically an example of a communicative tool. Like all such tools it is strategically and deliberately undertaken to satisfy a particular communicative purpose or objective. If these reports are genuinely being prepared in an attempt to improve the clarity of communication with stakeholders, and give related and necessary information accurately to them, then they become one of the strategic tools affecting performance positively.

This work offers a semantic examination of the English versions of annual reports from companies quoted on Borsa Istanbul (BIST) and included in the Corporate Governance Index (XKURY) to see whether the annual reports' tone has an impact on company performance. First, an efficiency score is obtained for 2 inputs (assets and number of employees in 2014) and 4 outputs (market capitalization, average price, book value per share and price/book value per share in 2015) by Data Envelopment Analysis (DEA). Then the contents of the 2014 annual reports are analyzed by the text-analysis software package Diction 7 and scores for accomplishment, 
cooperation, activity and optimism are obtained. Finally, efficiency scores are calculated by including content analyses scores and corporate governance ratings as inputs. This efficiency score is compared with the previous efficiency scores to evaluate to what extent annual reports' tone and corporate governance ratings (CGR) impact on company performance.

The study contributes to the literature regarding developing countries as well as the impact of tone in annual reports on company performance, a focus that has received little attention. This study differs from previous work on the subject both in terms of content analysis and companies under examination, and in terms of method, by making use of Diction 7 software and comparison of efficiency scores by DEA.

\section{LITERATURE REVIEW}

\subsection{Annual Reports and Disclosure}

If companies and countries want to grow, they require new investments. When their own resources are not enough for new investments external finance is required for development and for diversification. However, external investment can be provided only in a good investment environment. Thus, improving the quality of corporate governance is essential for global investors. In this regard, one of the principles of corporate governance is "public disclosure and transparency". In accordance with this principle, companies inform all interested parties about their financial situation, performance, ownership structure, strategies and other conditions and all related information in a timely and accurate manner. In this context the annual reports of companies are crucial, since they summarize and explain the financial and economic performance of the company, its strategies, accomplishments and future cooperation and expectations to all shareholders. These companies are becoming aware that the annual report is a potential tool for clients, investors, all shareholders and stakeholders.

Signaling theory says that (Spence, 1973) the main objective of firm disclosure is to inform analysts and investors of relevant information about firm quality and value. In this regard, Verrecchia (1983) suggests that corporate disclosure helps analysts and investors to predict future earnings, as corporate managers have to disclose value-relevant information. This suggests that voluntary disclosure decisions lead to the reporting of relevant information about firm performance.

In this regard, Clarke (1997) sees the annual reports as a shop window for all quoted company stocks and shares and, more importantly, a tool to reassure investors that the company is surviving and prospering in the long term. This stems from the fact that dealing with potential shareholder dissonance is vital for stable and long-term security in the stock market (Clarke, 1997; 32).

Based on these theoretical suggestions, prior studies have attempted to empirically examine the relevance of voluntary corporate disclosure. Some of the research in this field focused on companies web sites; for example, Cormier et al. (2009) examined the websites of 189 companies in Canada, Gandia (2008) examined the websites of 92 Spanish listed companies, Vergauwen et al. (2006) examined the websites of 270 companies in Austria, Belgium, France, the Netherlands, South Africa and the United Kingdom, and Branco et al. (2014) investigated the use of the Internet by the largest companies based in Sweden and Spain to communicate their engagement in corporate social responsibility. Some other research focused similarly on annual reports to determine the disclosure level of the companies: Sengupta (1998) used the data of total disclosure score for 311 different companies, Botosan (1997) measured 122 manufacturing firms' disclosure level, Silva and Alves (2004) calculated public disclosure level of 150 Brazilian, Argentinean and Mexican firms, Fan et al., (2003) worked with 144 Chinese companies, Huafang and Jianguo (2007) examined 559 Chinese companies' disclosure level, and Kahveci and Taliyev (2016) tested 92 Russian companies disclosure level (Kahveci \& Taliyev, 2016). There are also numerous studies that stress and examine executives' statements in annual reports (Hutt, 2010; Fiol, 1995). Studies have also shown that investors find the letters from companies' presidents in their annual reports a useful source of information.

The functions of annual reports have been analyzed from various research perspectives. One strand of the literature notes that the reports may have an impression management purpose, with the text, graphs and photographs directing the reader towards a favorable interpretation of corporate activities (Wisniewski \& 
Yekini, 2014). An in-depth literature review provided by Stanton and Stanton (2002) discusses the different theoretical viewpoints on annual reports.

There are then generally two types of research carried out in this area: (1) surveys of readers to ascertain their subjective opinions; and (2) analysis of content to make inferences about the author's or institution's intentions (Clarke, 1997; 33).

Hrasky and Smith (2008) assume corporate reporting is an important component of the investor relations function, and they look for evidence as to whether concise financial reports result in clearer communication between the company and its report users. In their study, characteristics of the chairperson's annual report letter and graph use in annual reports containing a concise financial report were compared to those in traditional full reports of listed Australian companies. According to their results, if concise reporters genuinely wish to improve the clarity of their communications, greater attention needs to be paid to how information is presented in their broader annual report (Hrasky \& Smith, 2008).

Hutt (2010) examined annual report letters from CEOs of publicly owned restaurant franchising companies in order to map the stakeholders of companies. Nineteen public restaurant franchisers, ranked by worldwide sales, on the Franchise Times (2007) top 200 list were used in this study. The CEOs' annual report letters for 2007 were analyzed using two features of the AntConc text analysis software: word list and keywords. The study found that CEO letters in annual reports include widely varying and extensive references to groups, organizations, and individuals, all of whom may be potential stakeholders of the organization. International and domestic franchisers used at the same time a unique set of references not used by the others and a variety of common references. Additionally, international franchisers tended to focus on customers and other output links while domestic franchisers attended more to management, employees, and other inputs links. His study proposed a methodology for using text analysis software, such as AntConc, to identify the groups, organizations, and individuals CEOs referred to in annual report letters (Hutt, 2010).

Lin et al. (2012) collected the annual reports of the 660 public listed companies in Taiwan and applied content analysis to company annual reports to obtain the disclosure information for human capital. They used human capital related keywords as the unit of analysis and counted the frequency of them to form an additive index of human capital disclosure. According to their results, human capital disclosure positively impacts on organizational performance such as market-to-book ratio and ROA. Organizational size negatively moderates the relationship between disclosure of human capital information and firm performance. Knowledge intensity has a curvilinear positive moderation effect on the relationship above. Firms engaging in knowledge-based competition can achieve better performance by disclosing human capital information when their knowledge intensity grows in a curvilinear fashion. Human capital disclosure also delivers important messages to employees and enhances operational and financial performance (Lin et al. 2012).

Hamrouni et al. (2015) empirically investigated the relationship between corporate voluntary disclosure and firm performance using a panel data of 1,074 firms-year listed on the Euronext Paris stock market. They used a non-parametric approach to measure firm performance via the technical efficiency. Using DEA, they measured a firm's ability to maximize its value (outputs) given a set of determinants (inputs). They used disclosure indexes which measure the extent of voluntary disclosure in annual reports. The empirical findings reveal a positive relationship between disclosure indexes and performance measures. They provide evidence that the level of voluntary information disclosed in annual reports plays a significant signaling role for firm performance. However, the extent of this role depends on the nature of the voluntary disclosure, i.e. whether it involves strategic, financial or corporate governance information (Hamrouni et al. 2015).

Nekhili et al. (2012) used a sample of 84 French listed firms over the 2000-2004 period and developed an R\&D disclosure index composed of 32 hand-collected items from annual reports. They examined whether voluntary $R \& D$ disclosure impacts the firm's market value, and whether it is influenced by ownership structure. According to their findings, voluntary R\&D disclosure improves the market value of equity, suggesting that the benefits from disclosures of R\&D activities exceed the disclosure costs. Another finding of their research is that the more French firms invest in R\&D, the larger the amount of R\&D-related information they disclose. Also, R\&D 
capitalization provides incentives for companies to disseminate more R\&D-related information (Nekhili et al. 2012).

Hamrouni and Ratsimbanier (2012) used DEA and stochastic frontier analysis models on a sample of 50 listed French firms belonging to the Sociétés des Bourses Françaises (SBF250) index from 2004 to 2008. They focused on the extent of voluntary disclosure in the annual reports measured using a composite disclosure index. Their results show that the level of disclosed information varies insignificantly across time for some firms and is similar for others (Hamrouni \& Ratsimbanier 2012).

Fiol (1995) compared executives' public and private statements to explore whether and along what dimensions public statements reflect internal company communications. Comparisons of internal and external documents generated by the forest products industry over ten years revealed no significant correlations in the two sets of documents between executives' positive or negative evaluations of events and situations; however, the correlations between their perceptions of control were positive and significant (Fiol 1995).

Manzoni (2007) applied DEA to the corporate social responsibility (CSR) management capacity dimensions of the organization behavior performance measurement framework in an Australian bank with national and international operations. DEA was applied to 231 Decision Making Units (DMU) of the bank to identify which were the most efficient CSR performers even though the bank itself had achieved premier gold star ratings on the national CSR indexes for the last four years. He used six factors as inputs for the singular corporate social responsibility output. These input factors were: 1) communication, 2) humanistic orientation, 3) integrated ethics, 4) commitment to ethics, 5) perceived organization support and 6) distributive justice (Manzoni, 2007).

\subsection{Content Analysis}

The task of categorizing text documents or summarizing them using quantitative measures may be neither straightforward nor easy to implement. Some authors have tried to achieve these objectives using human judgment (Hrasky \& Smith 2008; Kahveci \& Taliyev, 2016; Nekhili et al. 2012; Courtemanche et al., 2013; Fiol 1995; Hamrouni \& Ratsimbanier 2012; Clarke, 1997).

Recent advances in computational linguistics afford researchers the opportunity to utilize computerized approaches to content analysis. Such approaches rely on the construction of dictionaries that compile words with similar characteristics or meanings. Subsequently, the frequency with which these words occur in a particular text is measured, providing a reliable gauge of a given semantic dimension. Scott (2012) did a semantic network analysis used CATPAC; Hutt (2010) examined CEOs' annual report letters using AntConc. Wisniewski and Yekini (2014) used Diction 6.0 for content analysis of annual reports.

Today a variety of software for text analysis is available which support text analysis tasks within different disciplinary contexts in considerably different ways. Alexa and Zuell (2000) reviewed fifteen currently available software sets for text and discussed the tendencies both in functionality and technology of modern text analysis software. Of the 15 software packages they reviewed, the following typically are categorized as qualitative: AQUAD, ATLAS.ti, HyperRESEARCH, NUD_IST, QED and Win- MAXpro; CoAn, DICTION, DIMAPMCCA, KEDS, TEXTPACK, TextSmart and WordStat are categorized as quantitative ones. Code-A-Text and TATOE support operations which belong to both qualitative and quantitative analysis (Alexa \& Zuell, 2000).

Scott (2012) did a semantic network analysis using the abstracts from all the presentations from each of the past nine years of the conference on corporate communication to examine how the central themes in the study of corporate communication have changed over the years. She used a word co-occurrence program known as CATPAC. The semantic network analysis examined the relationship among the words of the abstracts to determine clusters of shared themes. Each year's worth of abstracts were examined in the form of a dendogram. In this way, how the themes of study have changed over the life of the Conference on Corporate Communication could be visualized and tracked. Although it is possible to see the change, the actual areas of study are subject to interpretation. It is possible to have a different interpretation based on the experience with the field (Scott, 2012).

Clarke (1997) examined annual reports to determine the differences in messages associated with the mission of the company: increasing share value, increasing dividends, or both. She also aimed to uncover differences in 
content resulting from positive and negative financial performance. She selected randomly 32 companies from a population of 156 investment companies quoted on the London Stock Exchange in 1994 that also subscribed to the Financial Times annual report service. She used content analysis to uncover the major themes in these annual reports. The methods included in the research were word frequency counts, KWIK-Key Word in Context and concordances which list words by type into construct categories (Clarke, 1997).

Courtemanche et al. (2013) examined the dynamic relationships between board capital, strategy and organizational environment. They conducted a 10-year (1997 - 2006) longitudinal case study of Bombardier Inc., a publicly traded global transportation company. According to their results, they found various links between four dimensions of board capital and changes at three strategic levels: institutional, corporate and business. There were significant changes in board human and relational capital over the period of analysis, even though board independence remained constant (Courtemanche et al., 2013).

Ege et al. (2013) examined 18 companies quoted on the BIST which are included in the corporate governance index to compare the financial performance results with corporate governance scores. They applied TOPSIS multi-criteria decision analysis method to obtain financial performance results. As the analysis results showed that rankings acquired from performance score and corporate governance score do not move accordingly. Besides this, the result shows that the quality of corporate governance of the companies does not have an influence on financial performance (Ege et al. 2013).

Branco et al. (2014) investigated the use of the Internet by the largest companies based in Sweden and Spain to communicate their engagement in CSR activities. Non-parametric statistics were used to analyze some factors that influence disclosure, namely country, industry affiliation, profitability, and size. Their findings suggest that in spite of the existence of a high degree of similarity between CSR communication practices, companies from Spain place social responsibility information in more prominent sections and devote more space to said information. Swedish companies are found to disclose more their codes of conduct/ethics and CSR-related press clips and published articles. (Manuel et al., 2014).

Performance should be analyzed beyond financial ratios criteria and systems, and should be measured in terms of corporate governance, organization behavior and supply chain management because these factors determine the performance of enterprises in the broader socio-economic perspective generally, and corporate social responsibility specifically (Manzoni, 2007).

Wisniewski and Yekini (2014) examined the entire narrative included in annual report, as the content analysis of longer texts can provide a more reliable indication of style and language. They employed a computerassisted approach to counting the frequencies of words falling into particular categories - categories that appear to matter to financial markets. They used Diction 6.0 as text analysis software (Wisniewski \& Yekini, 2014).

Jeanjean et al. (2015) studied the economic consequences of non-English-speaking companies adopting English as an external reporting language. They collected a sample of 102 companies that initiated the issuance of an annual report in English (i.e., in addition to the local language annual report). According to their findings issuing an annual report in English in addition to the local-language report is associated with a decrease in information asymmetry, an increase in analyst following, and an increase foreign investor ownership (Jeanjean et al. 2015).

\section{DATA AND METHODOLOGY}

\subsection{Research Goal}

In this research, consistent with previous works, our aim is to use annual reports as a voluntary disclosure tool (Sengupta 1998; Botosan, 1997; Silva \& Alves, 2004; Fan et al., 2003; Huafang \& Jianguo, 2007; Kahveci and Taliyev, 2016) and to carry out a content analysis of the reports to quantify the data to evaluate the effect of one year's annual reports tone about the future path of firm on the next year's performance and efficiency by using DEA as an analytical tool. DEA measures relative performance (efficiency) and is useful in comparing organizations or parts of organizations that share common goals, use similar resources (but not necessarily in the same proportions) and produce similar results (Rouse et al. 2010). DEA uses multiple inputs to produce 
multiple outputs. DEA identifies DMUs that produce the largest amount of output by consuming the least amount of input. These DMUs are classified as efficient (Cooper et al., 2006).

Moreover, we utilized a text-analysis software package (Scott, 2012; CATPAC; Hutt, 2010; AntConc.; Wisniewski and Yekini, (2014); Diction 6.0) called Diction 7. Diction 7 is a computer-based program that searches a passage for five general lexical features as well as thirty-five sub-features to determine the tone of a verbal message. The software conducts its searches via a 10,000-word corpus and up to thirty user-created custom dictionaries that allow researchers to specific topical or negative words for particular research objectives. By now, as a quantitative (Alexa \& Zuell, 2000) text analysis software, Diction is well-established within the academic community, with many studies relying on it as a content analysis method, particularly in the fields of political science, communication and language analysis, as well as in media studies. A full list of books and academic articles that engage with Diction can be found on the software's web page ${ }^{1}$.

We used two master variables out of five that we believe are important in terms of future behavior and future attributions: Certainty and Optimism. The two master variables are defined below (Diction 7, 2016):

- Optimism - Language endorsing some person, group, concept or event, or highlighting their positive entailments.

- Activity - Language featuring movement, change, the implementation of ideas and the avoidance of inertia.

Besides the two master variables, two dictionaries, accomplishment and cooperation, out of 31 are used as inputs. It is believed that all four variables, optimism, activity, accomplishment and cooperation, are important and significant in terms of future action, behavior and attributes of the company. Detailed information about the master variables is given in Appendix A.

The four Diction scores have been chosen as the evaluative criteria since it has been believed that optimism is related to how a company is optimistic about its future, cooperation is related to what kind of cooperation a company will carry out, activity is related to how actively a company is committed to investments, cooperation, marketing strategies and generally to how company would follow a proactive strategy and lastly accomplishment is related to what kind of accomplishment a company obtained and to what kind of accomplishment a company would expect in the future.

\subsection{The model and selection of inputs, outputs}

In order to evaluate XKURY companies quoted on BIST, we used two different models shown in figure 1 and figure 2. In first model, efficiency scores are obtained for two inputs: assets (Feroz et al, 2003; Samad \& Patwary, 2003; Ulucan, 2000 and 2002; Zhu, 2000; Nath et al., 2008) and number of employees (Sueyoshi et al., 2010; Chandra et al., 1998; Kim et al., 2009; Samad \& Patwary, 2003; Ulucan, 2000 and 2002; Zhu, 2000; Kahveci, 2011) in 2014 and four outputs: market capitalization (Ulucan, 2000 and 2002; Zhu, 2000; Kahveci, 2011), average price, book value per share and price/book value per share in 2015. Then the contents of the 2014 annual reports were analyzed by text-analysis software package Diction 7 and scores for accomplishment, cooperation, activity and optimism are obtained. Then, in second stage, content analyses scores and CGRs are added to the model as inputs and efficiency scores are calculated accordingly. Second stage efficiency scores are then compared with the first stage efficiency scores to evaluate to what extent annual reports tone and CGRs impact company performance. By doing this, it has been evaluated how the scores of the tone of future expressions in annual reports and the corporate governance ratings given by the independent rating institutions impact on the company's efficiency scores. Efficiency scores are calculated by MaxDea software.

\footnotetext{
${ }^{1}$ Please see: http://www.dictionsoftware.com/published-studies/
} 
Figure 1: Model 1 for 45 DMU XKURY Index Firms of BIST

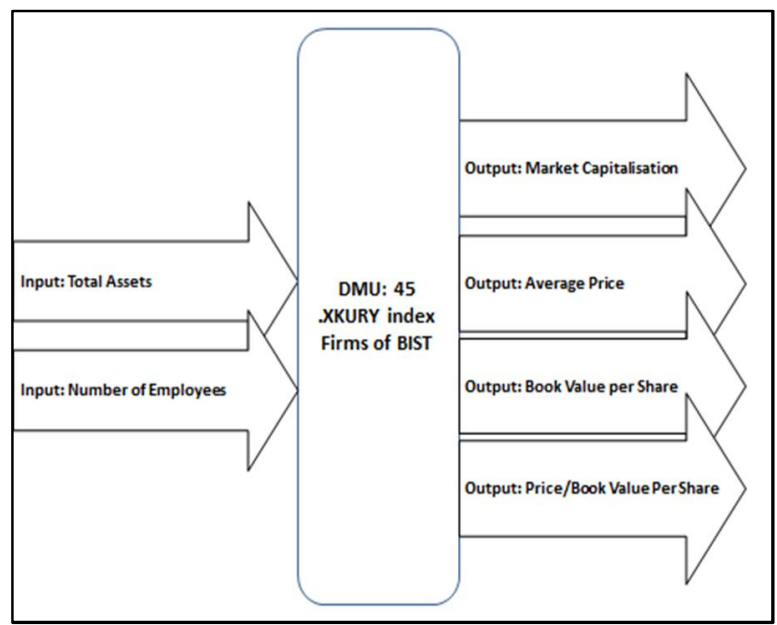

Figure 2: Model 2 for 45 DMU XKURY Index Firms of BIST

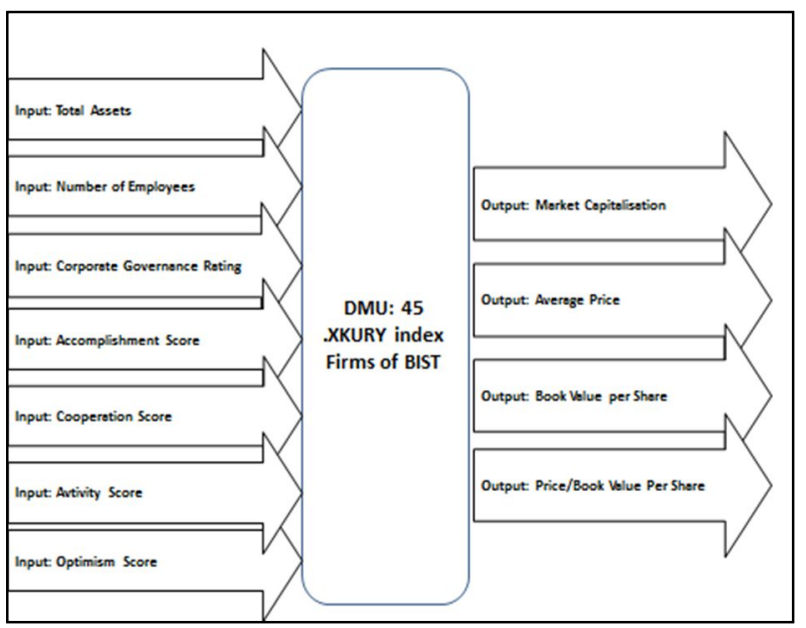

\subsection{Sample and Data Collection}

Based on signaling theory (Spence 1973), we considered corporate voluntary disclosure, and in this study it is assumed that annual reports function, as a signaling instrument reporting firm performance to investors and financial analysts.

Fifty companies included in the XKURY of BIST were chosen as a sample. We argue that the annual report language can be an information processing constraint and a barrier to foreign investment and that using English for external reporting purposes is a potential strategy for companies in non-English-speaking countries to reduce the information frictions and to, therefore, increase the accessibility of the company's financial statements for investors and analysts. It is believed that companies included in the XKURY index are the best companies in Turkey in terms of corporate governance practices and they must target both domestic and foreign investors, therefore, they prepare the best annual reports in English in Turkey. That is the reason why we decided to use the English version of their annual reports in this research. Of the 50 companies included in XKURY, 45 are used in this research since four of them do not have any annual report in English for 2014 and one of the company's data could not be obtained from Reuters.

The BIST XKURY aims to measure the price and return performances of companies traded on Borsa Istanbul Markets (except companies on the Watch List and Lists $C$ and D) with a corporate governance rating of a minimum 7 out of 10 as a whole and a minimum of 6.5 for each main section. The corporate governance rating is determined by the rating institutions incorporated by the Capital Markets Board in its list of rating agencies as a result of their assessment of the company's compliance with corporate governance principles.

It is important to examine annual reports for the extent to which they accurately communicated what managers do or what managers think, in other words, managers' interpretations of their activities and their environments. The potentially important indicators of subsequent decisions and actions are managers' interpretations of the future. Fiol (1995) says if one's aim is to identify the interpretive frames of reference that guide future behaviors, the appropriate focus is on the future rather than past attributions (Fiol, 1995). Consistent with this suggestion we used 2014 annual reports to evaluate 2015 performances. The 2014 annual reports and the 2014 corporate governance ratings should give some insight to investor for 2015, and company's 2015 performance should be affected accordingly. In this context, companies' annual reports of 2014 and CGRs of 2014 were obtained from their websites, and year-end 2015 financial data obtained from the Reuters terminal. Then, calculated Diction 7 scores are used as inputs with CGRs to see company's efficiency in terms of their performance. 


\section{FINDINGS AND DISCUSSIONS}

Firstly efficiency scores are calculated by using companies' assets and number of employees in 2014 as input and average price, market capitalization, book value per share and price/book value per share of 2015 as output. Then, secondly scores of the tone of future expressions in annual reports and the corporate governance ratings given by the independent rating institutions are added to the model as inputs and efficiency scores are calculated for model 2 . In this stage the message given in annual reports and companies' corporate governing ratings are accepted as corporate governance implementations and by adding these inputs to the model it enables us to see how and to what extent corporate governance implementations impact on companies' efficiency scores. It should also be noted that the traditional DEA models can be analyzed in two ways, an input orientation or an output orientation. The objective of an input oriented model is to minimize inputs while producing at least the given output levels, on the other hand, the objective of an output oriented model is to maximize outputs while using no more than the observed amount of any input. (Cooper et al., 2000). In terms of this study, we believe that it is appropriate to adopt an output maximization assumption since it is widely accepted in strategy research that the main aim of the firm is to maximize market value. Thus, the firm using given inputs should be able to maximize market value and so market price.

Developed by Charnes, Cooper and Rhodes (CCR) (1978) a model with Constant Returns to Scale (CRS) are used for technical efficiency, on the other hand, developed by Banker, Charnes and Cooper (BCC) (1984) a model with Variable Returns to Scale (VRS) are used for pure technical efficiency. If technically efficient DMU has an inefficiency coming from scale inefficiency, it cannot be technically (totally) efficient. Farrell (1957) describes technical efficiency in terms of a firm's success at producing the maximum level of outputs from a given set of inputs employed. The technical efficiency (TE) score generated by DEA for a DMU is a relative measure showing the particular DMU's input-output conversion performance relative to all other DMUs in that particular sample. Scale efficiency (SE), on the other hand, compares the input-output conversion performance of a hypothetical firm that is $100 \%$ efficient under VRS with the input-output conversion performance of another hypothetical firm (of the same size) that is efficient under CRS. The relation between technical efficiency and pure technical efficiency is shown by the equation below (Cooper et al, 2006: 141; Ulucan, 2002; Kahveci, 2011).

\section{Technical efficiency $=$ Pure technical efficiency $X$ Scale efficiency}

All the results are given in table 1 . When the results are analyzed, it becomes very clear that corporate governance implementation has a significant positive impact on the efficiency scores of companies. Average technical efficiency score was 0.43 , pure technical efficiency was 0.70 and average scale efficiency was 0.61 in the first stage and increased to $0.75,0.86$ and 0.88 respectively in the second stage. On the other hand, while there are five firms which have technical and scale efficiency and are eighteen firms which have pure technical efficiency in the first stage there are twenty firms which have technical and scale efficiency and twenty eight firms which have pure technical efficiency in the second stage. Efficient firms have significantly increased when scores of the tone of future expressions in annual reports and corporate governance ratings added as inputs to the evaluation as seen in figure 3 and figure 4. 
Table 1: Efficiency Scores of DMUs in Both Stages

\begin{tabular}{|c|c|c|c|c|c|c|}
\hline \multirow[t]{2}{*}{ DMUs } & \multicolumn{3}{|c|}{ First Stage } & \multicolumn{3}{|c|}{ Second Stage } \\
\hline & $\begin{array}{l}\text { Technical } \\
\text { Efficiency } \\
\text { Score(CRS) }\end{array}$ & $\begin{array}{c}\text { Pure Technical } \\
\text { Efficiency } \\
\text { Score(VRS) }\end{array}$ & $\begin{array}{c}\text { Scale } \\
\text { Efficiency } \\
\text { Score }\end{array}$ & $\begin{array}{l}\text { Technical } \\
\text { Efficiency } \\
\text { Score(CRS) }\end{array}$ & $\begin{array}{c}\text { Pure Technical } \\
\text { Efficiency } \\
\text { Score(VRS) }\end{array}$ & $\begin{array}{c}\text { Scale Efficiency } \\
\text { Score }\end{array}$ \\
\hline AEFES.IS & 0,25 & 0,63 & 0,39 & 0,63 & 0,72 & 0,88 \\
\hline AKSA.IS & 0,63 & 0,80 & 0,79 & 0,81 & 0,81 & 1,00 \\
\hline ALBRK.IS & 0,08 & 0,11 & 0,71 & 1,00 & 1,00 & 1,00 \\
\hline ANSGR.IS & 0,22 & 0,24 & 0,89 & 0,25 & 0,35 & 0,72 \\
\hline ARCLK.IS & 0,16 & 0,72 & 0,23 & 0,73 & 0,74 & 0,99 \\
\hline ASELS.IS & 0,67 & 1,00 & 0,67 & 1,00 & 1,00 & 1,00 \\
\hline AYGAZ.IS & 0,71 & 0,88 & 0,81 & 0,88 & 0,88 & 0,99 \\
\hline CCOLA.IS & 0,39 & 1,00 & 0,39 & 1,00 & 1,00 & 1,00 \\
\hline CRDFA.IS & 0,91 & 1,00 & 0,91 & 1,00 & 1,00 & 1,00 \\
\hline DOAS.IS & 0,39 & 0,59 & 0,66 & 0,61 & 0,62 & 0,99 \\
\hline DOHOL.IS & 0,55 & 0,95 & 0,58 & 1,00 & 1,00 & 1,00 \\
\hline ENKAI.IS & 0,34 & 1,00 & 0,34 & 1,00 & 1,00 & 1,00 \\
\hline EREGL.IS & 0,33 & 0,72 & 0,46 & 0,84 & 0,95 & 0,89 \\
\hline GARAN.IS & 0,20 & 1,00 & 0,20 & 1,00 & 1,00 & 1,00 \\
\hline GARFA.IS & 0,33 & 0,43 & 0,76 & 0,63 & 1,00 & 0,63 \\
\hline GLYHO.IS & 0,11 & 0,18 & 0,58 & 0,24 & 1,00 & 0,24 \\
\hline HALKB.IS & 0,13 & 0,64 & 0,20 & 0,65 & 0,67 & 0,96 \\
\hline HURGZ.IS & 0,06 & 0,10 & 0,60 & 0,15 & 0,23 & 0,66 \\
\hline IHEVA.IS & 0,23 & 0,26 & 0,89 & 0,25 & 1,00 & 0,25 \\
\hline IHLAS.IS & 0,03 & 0,05 & 0,48 & 0,14 & 1,00 & 0,14 \\
\hline ISFIN.IS & 0,21 & 0,30 & 0,70 & 0,57 & 1,00 & 0,57 \\
\hline ISGYO.IS & 1,00 & 1,00 & 1,00 & 1,00 & 1,00 & 1,00 \\
\hline ISMEN.IS & 0,15 & 0,28 & 0,55 & 0,39 & 0,50 & 0,77 \\
\hline IZOCM.IS & 1,00 & 1,00 & 1,00 & 1,00 & 1,00 & 1,00 \\
\hline LOGO.IS & 1,00 & 1,00 & 1,00 & 1,00 & 1,00 & 1,00 \\
\hline MGROS.IS & 0,08 & 0,65 & 0,13 & 0,67 & 0,71 & 0,95 \\
\hline OTKAR.IS & 0,60 & 1,00 & 0,60 & 1,00 & 1,00 & 1,00 \\
\hline PETKM.IS & 0,71 & 0,94 & 0,76 & 0,94 & 0,94 & 1,00 \\
\hline PETUN.IS & 0,77 & 0,91 & 0,85 & 0,91 & 1,00 & 0,91 \\
\hline PGSUS.IS & 0,18 & 0,79 & 0,23 & 0,87 & 1,00 & 0,87 \\
\hline PINSU.IS & 1,00 & 1,00 & 1,00 & 1,00 & 1,00 & 1,00 \\
\hline PNSUT.IS & 0,80 & 1,00 & 0,80 & 1,00 & 1,00 & 1,00 \\
\hline PRKAB.IS & 0,28 & 0,28 & 0,99 & 0,28 & 0,29 & 0,98 \\
\hline PRKME.IS & 0,46 & 0,47 & 0,97 & 0,53 & 0,62 & 0,85 \\
\hline SISE.IS & 0,13 & 0,45 & 0,28 & 0,56 & 0,64 & 0,88 \\
\hline SKBNK.IS & 0,11 & 0,15 & 0,70 & 0,37 & 1,00 & 0,37 \\
\hline TAVHL.IS & 0,33 & 1,00 & 0,33 & 1,00 & 1,00 & 1,00 \\
\hline TOASO.IS & 0,56 & 1,00 & 0,56 & 1,00 & 1,00 & 1,00 \\
\hline TRCAS.IS & 1,00 & 1,00 & 1,00 & 1,00 & 1,00 & 1,00 \\
\hline TSKB.IS & 0,36 & 1,00 & 0,36 & 1,00 & 1,00 & 1,00 \\
\hline TTKOM.IS & 0,25 & 1,00 & 0,25 & 1,00 & 1,00 & 1,00 \\
\hline TTRAK.IS & 0,55 & 1,00 & 0,55 & 1,00 & 1,00 & 1,00 \\
\hline TUPRS.IS & 0,86 & 1,00 & 0,86 & 1,00 & 1,00 & 1,00 \\
\hline VESTL.IS & 0,05 & 0,26 & 0,19 & 0,30 & 0,31 & 0,94 \\
\hline YKBNK.IS & 0,14 & 0,60 & 0,23 & 0,70 & 0,70 & 0,99 \\
\hline Average Score & 0,43 & 0,70 & 0,61 & 0,75 & 0,86 & 0,88 \\
\hline
\end{tabular}


Figure 3: Comparison of Efficient Number of Firms

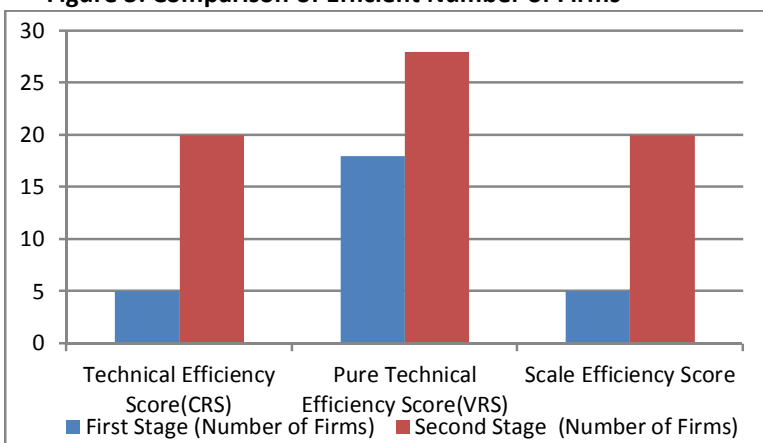

Figure 4: Comparison of Average Efficiency Scores

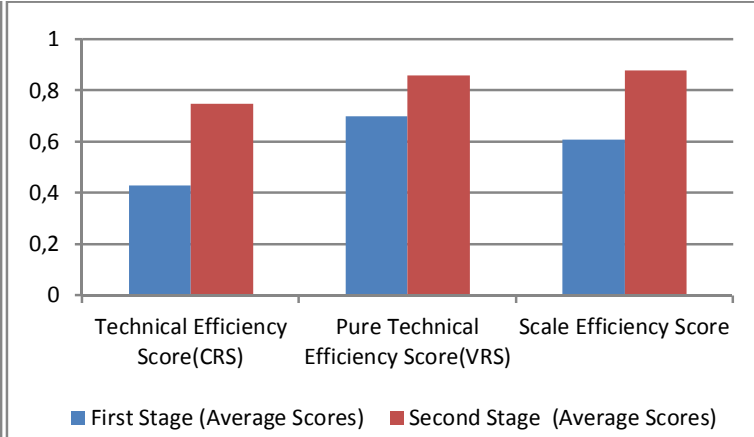

When we look at the scores in terms of the sectoral groups manufacturing industry's technical efficiency was 0.55 and scale efficiency was 0.68 , whereas financial sector's was 0.29 and 0.67 , for others it was 0.42 and 0.62 respectively (Table 2). The firms operating in manufacturing industry have higher TE and SE scores in the first stages. Other firms (a group including one firm in mining, one firm in construction and public works, two firms in technology, two firms in wholesale trade and two firms in transportation, telecommunication and storage sector) have higher TE and SE efficiency scores in the second stage and have higher PTE score in the first stage. Firms in the financial sector have higher PTE scores in the second stage. From these scores, it can be concluded that firms operating in the manufacturing sector has higher efficiency in the first stage and firms operating in financial and in other sector have higher efficiency in the second stage. This conclusion can be interpreted as demonstrating that: the tone of future expressions in annual reports and corporate governance ratings have more positive impacts on the performance of firms in the financial and other sectors, compared to manufacturing sector firms.

Table 2: Comparison of Sectoral Efficiency Scores in Both Stages

\begin{tabular}{|c|c|c|c|c|c|c|}
\hline \multirow[t]{2}{*}{ Sector } & \multicolumn{3}{|c|}{ First Stage (Average Scores) } & \multicolumn{3}{|c|}{ Second Stage (Average Scores) } \\
\hline & $\begin{array}{c}\text { Technical } \\
\text { Efficiency Score } \\
\text { (CRS) }\end{array}$ & $\begin{array}{c}\text { Pure Technical } \\
\text { Efficiency Score } \\
\text { (VRS) }\end{array}$ & $\begin{array}{c}\text { Scale Efficiency } \\
\text { Score }\end{array}$ & $\begin{array}{c}\text { Technical } \\
\text { Efficiency Score } \\
\text { (CRS) }\end{array}$ & $\begin{array}{c}\text { Pure Technical } \\
\text { Efficiency Score } \\
\text { (VRS) }\end{array}$ & $\begin{array}{c}\text { Scale } \\
\text { Efficiency } \\
\text { Score }\end{array}$ \\
\hline Manufacturing & 0,55 & 0,77 & 0,69 & 0,79 & 0,84 & 0,92 \\
\hline Financial & 0,32 & 0,60 & 0,60 & 0,72 & 0,92 & 0,84 \\
\hline Other & 0,42 & 0,81 & 0,53 & 0,83 & 0,87 & 0,96 \\
\hline
\end{tabular}

It is important to emphasize that fully efficient DMUs form a best practice production frontier and are benchmark peers for inefficient DMUs. Table 3, shows how many times an efficient DMU is used as a benchmark for another DMU in both stages. In the first stage, ISGYO.IS, IZOCM.IS and LOGO.IS are the most benchmarked firms in both CRS and VRS models, whereas TUPRS.IS and ASELS.IS are the most benchmarked firms only in the VRS model. However, in the second stage, IZOCM.IS and LOGO.IS continued as the most benchmarked firms and PNSUT.IS, TTRAK.IS and TUPRS.IS are added as the most benchmarked firms. In other words, IZOCM.IS, LOGO.IS, PNSUT.IS, TTRAK.IS and TUPRS.IS are the most benchmarked efficient firms in the second stage, which means their tone of future expressions in annual reports and corporate governance ratings have more positive impacts on their performance compared to other firms and if other firms use those firms as a benchmark for their applications they would have higher performance. 
Table 3: Comparison of How Many Times an Efficient DMU is Used as a Benchmark for Another DMU

\begin{tabular}{|c|c|c|c|c|}
\hline DMU & First Stage & & Second Stage & \\
\hline & $\begin{array}{c}\text { Times as a benchmark for } \\
\text { another DMU (VRS) }\end{array}$ & $\begin{array}{c}\text { Times as a benchmark for } \\
\text { another DMU (CRS) }\end{array}$ & $\begin{array}{c}\text { Times as a benchmark for } \\
\text { another DMU (VRS) }\end{array}$ & $\begin{array}{c}\text { Times as a benchmark for } \\
\text { another DMU (CRS) }\end{array}$ \\
\hline ALBRK.IS & - & - & 1 & - \\
\hline ASELS.IS & 9 & - & 4 & 4 \\
\hline CCOLA.IS & - & - & 3 & 2 \\
\hline CRDFA.IS & 1 & - & 5 & 1 \\
\hline ENKAI.IS & 1 & - & 1 & - \\
\hline GARAN.IS & 5 & - & 4 & 4 \\
\hline GARFA.IS & - & - & 4 & - \\
\hline GLYHO.IS & - & - & 1 & - \\
\hline IHEVA.IS & - & - & 2 & - \\
\hline IHLAS.IS & - & - & 4 & - \\
\hline ISFIN.IS & - & - & 3 & - \\
\hline ISGYO.IS & 8 & 37 & 1 & 7 \\
\hline IZOCM.IS & 11 & 13 & 6 & 13 \\
\hline LOGO.IS & 12 & 37 & 10 & 11 \\
\hline OTKAR.IS & 7 & - & 3 & 5 \\
\hline PETUN.IS & - & - & 1 & - \\
\hline PINSU.IS & 2 & 5 & 1 & 2 \\
\hline PNSUT.IS & 3 & - & 6 & 9 \\
\hline TAVHL.IS & 1 & - & 3 & 3 \\
\hline TOASO.IS & - & - & 1 & - \\
\hline TRCAS.IS & 1 & 4 & - & - \\
\hline TSKB.IS & 1 & - & - & - \\
\hline TTKOM.IS & 5 & - & 4 & 4 \\
\hline TTRAK.IS & 6 & - & 6 & 8 \\
\hline TUPRS.IS & 21 & - & 13 & 20 \\
\hline
\end{tabular}

\section{CONCLUSION}

As a conclusion, corporate governance implementation scores of the tone of future expressions in annual reports and the corporate governance ratings given by the independent rating institutions have positive effects on companies' efficiency scores. In terms of sectoral efficiency, firms operating in the manufacturing sector have higher efficiency in the first stage and firms operating in financial and in other sector have higher efficiency in the second stage. This can be interpreted as demonstrating that: the tone of future expressions in annual reports and corporate governance ratings have more positive impacts on the performance of firms in the financial and other sectors, compared to manufacturing sector firms. In terms of firms' benchmarking position; IZOCM.IS, LOGO.IS, PNSUT.IS, TTRAK.IS and TUPRS.IS are the most benchmarked efficient firms in the second stage, which means their tone of future expressions in annual reports and corporate governance ratings have more positive impacts on their performance compared to other firms and if other firms use those firms as a benchmark for their applications they would have higher performance.

The study contributes to the literature regarding the impact of tone in annual reports on company performance, a focus that has received little attention. This study differs from previous work on the subject both in terms of content analysis and companies under examination, and in terms of method, by making use of Diction 7 software and comparison of efficiency scores with DEA. On the other hand, the practical implication of this study is the annual reports of companies are crucial, since they summarize and explain the financial and economic performance of the company, its strategies, accomplishments and future cooperation and expectations to all shareholders. As a strategic communication tool, choosing the right words and statements is crucial to attract additional new investments and to increase the value of the firm. Turkish companies might improve the optimistic, cooperative, activism and accomplishment tone of annual reports as an efficient corporate governance implementation. Good corporate governance rating would also help.

For further researches, similar studies can be conducted to see how the tone of annual reports and efficiency scores change over the years. Besides, comparison of Diction scores among different countries can be carried out to see the differences among countries and the effects on the firm performances. 


\section{REFERENCES}

Botosan, C.A., (1997). Disclosure level and the cost of equity capital. The Accounting Review, 72 (3), 323-349.

Branco M.C., Delgado C., Sa M., \& Sousa C. (2014). Comparing CSR communication on corporate web sites in Sweden and Spain. Baltic Journal of Management, 9, (2), 231-250.

Banker, R.D., Charnes, R.F., \& Cooper, W.W. (1984). Some models for estimating technical and scale inefficiencies in data envelopment analysis. Management Science, 30, 1078-1092.

Charnes, A., Cooper, W. W. \& Rhodes E. (1978). Measuring the efficiency of decision-making units. European Journal of Operational Research, 2, 429-444.

Clarke Geraldine (1997). Messages from CEOs: A content analysis approach. Corporate Communications 2(1), 31-39.

Cooper, W. W., Seiford, L. M., Tone, K.., (2006). Introductionto Data Envelopment Analysis and Its Uses, Springer.

Cormier, D., Ledoux, M., \& Magnan, M., (2009). The use of web sites as a disclosure platform for corporate performance. International Journal of Accounting Information Systems, 10(1), 1-24.

Courtemanche, L., Côté, L., \& Schiehll, E., (2013). Board capital and strategic turnaround: A longitudinal case study. International Journal of Disclosure and Governance, 10(4), 378-405.

Diction 7 Help Manual (2015). http://www.dictionsoftware.com/download.php?file=wp-content/uploads/2015/07/DICTION-7.1Manual.pdf

Ege, İ., Topaloğlu E. E., \& Özyamanoğlu, M., (2013). Finansal performans ile kurumsal yönetim notları arasındaki ilişki: BIST üzerine bir uygulama. Akademik Araştırmalar ve Çalışmalar Dergisi, 5(9), 100-117.

Fan, Z., Wang, L., \& Zhang, J.,(2003). Corporate competitive strategy and voluntary disclosure. Social Science Electronic Publishing, Inc.: http://papers.ssrn.com/sol3/papers.cfm?abstract id=1106614

Feroz, E.H., Kim, S., \& Raab, R.L., (2003). Financial statement analysis: A data envelopment analysis approach. Journal of the Operational Research Society, 54, 48-58.

Fiol, C. M. (1995). Corporate communications: Comparing executives' private and public statements . Academy of Management Journal, $38(2), 522-536$

Gandia, J. L., (2008), Determinants of internet-based corporate governance disclosure by Spanish listed companies. Online Information Review. 32(6), 791-817.

Hamrouni, A., Miloudi, A., \& Benkraiem, R. (2015). Signaling firm performance through corporate voluntary disclosure. Journal of Applied Business Research, 31(2), 609-620.

Hamrouni, A. \& Ratsimbanierana, H. (2012). The extent of voluntary information in the annual report and the share price volatility: Application of DEA and SFA on the French market. The Journal of Modern Accounting and Auditing, 8(7), 951-966

Hrasky, S., \& Smith, B. (2008). Concise corporate reporting: Communication or symbolism? Corporate Communications, 13(4), 418-432.

Huafang, X., \& Jianguo, Y., (2007). Ownership structure, board composition and corporate voluntary disclosure. Evidence from listed companies in China. Managerial Auditing Journal, 22(6), 604-619.

Hutt, R. W. (2010). Identifying and mapping stakeholders: An industry case study. Corporate Communications, 15(2), $181-191$.

Jeanjean, T., Stolowy, H., Erkens, M., \& Yohn, T. L. (2015). International evidence on the impact of adopting english as an external reporting language. Journal of International Business Studies, 46(2), 180-205.

Kahveci, E., (2011) Firm performance and resource-based theory: an application with DEA. International Journal of Contemporary Business Studies, 2(4), 38-50.

Kahveci, E. and Taliyev, R.(2016) The Disclosure Behavior and Performance of Russian Firms: Public Disclosure Index and DEA Application. In progress.

Lin, Y., Chang, H., Chen, J., \& Wu, G. (2014). Accounting disclosure quality, capital market intensity and national productivity. Annals of Operations Research, 221(1), 239-254.

Manzoni, A. (2007). A New Approach to Performance Measurement Using Data Envelopment Analysis: Implications for Organisation Behaviour, Corporate Governance and Supply Chain Management. Victoria University Doctoral Thesis, Victoria Graduate School of Business, Faculty of Business and Law.

Nath, P., Nachiappan, S., \& Ramanathan, R. (2010). The impact of marketing capability, operations capability and diversification strategy on performance: A resource-based view. Industrial Marketing Management, 39(2), 317-329.

Nekhili, M., Boubaker, S., \& Lakhal, F. (2012). Ownership structure, voluntary R\&D disclosure and market value of firms: The french case. International Journal of Business, 17(2), 126-140. 
Rouse, P., Chen, L. \& Harrison, J.A. (2010). Data envelopment analysis: a practical tool to measure performance. Australian Accounting Review, 20(2), 165-177.

Sengupta, P., (1998). Corporate disclosure quality and the cost of debt. The Accounting Review, 73(4), 459-474.

Silva, W. M., \& Alves, L.A., (2004), The Voluntary Disclosure of Financial Information on the Internet and theFirm Value Effect in Companies Across Latin America, Social Science Electronic Publishing, Inc.: http://www.ssrn.com.

Samad, Q., A., \& Patwary, F., K., (2003). Technical efficiency in the textile industry of Bangladesh: An application of frontier production function. Information and Management Sciences, 14(1), 19-30.

Scott, Patricia B. (2012). How is the study of communication changing? Corporate Communications: An International Journal, 17(3), 350357.

Sueyoshi, T., Mika Goto, \& Yusuke Omi, (2010). Corporate governance and firm performance: Evidence from Japanese manufacturing industries after the lost decade. European Journal of Operational Research, 203, 724-736.

Spence, M., (1973), Job Market Signaling. The Quarterly Journal of Economics, 87(3), 355-374.

Ulucan, A., (2000). Şirket performanslarının ölçülmesinde veri zarflama analizi yaklaşımı: genel ve sektörel bazda değerlendirmeler. Hacettepe Üniversitesi Iktisadi ve Idari Bilimler Fakültesi Dergisi, 18(1), 419-437.

Ulucan, A., (2002). ISO500 şirketlerinin etkinliklerinin ölçülmesinde veri zarflama analizi yaklaşımı:farklı girdi çıktı bileşenleri ve ölçeğe göre getiri yaklaşımları ile değerlendirmeler. Ankara Üniversitesi SBF Dergisi, 57(2), 182-202.

Verrecchia, R E. (1983). Discretionary disclosure. Journal Of Accounting \& Economics, 5(3), 179-194.

Vergauwen, P., Bollen, L., \& Oirbans, E. (2007). Intellectual capital disclosure and intangible value drivers: An empirical study. Management Decision, 45(7), 1163.

Wisniewski, T. P.,\& Yekini, L. S. (2014). Predicting stock market returns based on the content of annual report narrative: A new anomaly. St. Louis: Federal Reserve Bank of St Louis. https://ideas.repec.org/p/pra/mprapa/58107.html

Zhu, J,. (2000). Multi-factor performance measure model with an application to Fortune 500 companies. European Journal of Operational Research, 123, $105-124$.

\section{Appendix A: Diction 7 Master Variables}

\begin{tabular}{|c|c|c|}
\hline Master Variable & Definition & Formula \\
\hline Certainty & $\begin{array}{l}\text { Language indicating resoluteness, inflexibility, and } \\
\text { completeness and a tendency to speak ex cathedra }\end{array}$ & $\begin{array}{l}\text { [Tenacity + Leveling + Collectives + Insistence }] \text { - [Numerical } \\
\text { Terms + Ambivalence + Self Reference + Variety }]\end{array}$ \\
\hline Optimism & $\begin{array}{l}\text { Language endorsing some person, group, concept or } \\
\text { event or highlighting their positive entailments. }\end{array}$ & $\begin{array}{l}\text { [Praise + Satisfaction + Inspiration }]-[\text { Blame + Hardship + } \\
\text { Denial }]\end{array}$ \\
\hline Activity & $\begin{array}{l}\text { Language featuring movement, change, the } \\
\text { implementation of ideas and the avoidance of inertia. }\end{array}$ & $\begin{array}{l}\text { [Aggression + Accomplishment + Communication + Motion }] \\
-[\text { Cognition + Passivity + Embellishment }]\end{array}$ \\
\hline Realism & $\begin{array}{l}\text { Language describing tangible, immediate, recognizable } \\
\text { matters that affect people's everyday lives. }\end{array}$ & $\begin{array}{l}\text { [Familiarity + Spatial Terms + Temporal Terms + Present } \\
\text { Concern + Human Interest + Concreteness }]-[\text { Past Concern } \\
+ \text { Complexity] }\end{array}$ \\
\hline Commonality & $\begin{array}{l}\text { Language highlighting the agreed -upon values of a group } \\
\text { and rejecting idiosyncratic modes of engagement. }\end{array}$ & $\begin{array}{l}\text { [Centrality + Cooperation + Rapport] }- \text { [Diversity + Exclusion } \\
+ \text { Liberation] }\end{array}$ \\
\hline
\end{tabular}

Source: Diction 7 Help Manual, 2015, p. 5. 